\title{
Heterogenization of Alkene Epoxidation Catalysts
}

\author{
Regina Buffon ${ }^{*}$ and Ulf Schuchardt ${ }^{*, \#}$ \\ Instituto de Química, Universidade Estadual de Campinas, CP 6154, 13084-971 Campinas - SP, Brazil
}

\begin{abstract}
Este trabalho descreve nosso esforço em heterogeneizar catalisadores para epoxidação. Tanto o molibdênio ancorado quanto o engaiolado pelo método de sol-gel mostraram grande seletividade, mas possuem suas atividades fortemente reduzidas. Por outro lado, silicatos de molibdênio foram muito ativos e estáveis até a formação de diols na mistura reacional. Catalisadores heterogeneizados de rênio foram menos ativos, mas permitiram o uso do peróxido de hidrogênio anidro como oxidante. Contudo, o alto custo e a dificuldade de regeneração impedem a aplicação industrial destes catalisadores. Durante estas investigações, descobrimos que a alumina sozinha é ativa para epoxidação com peróxido de hidrogênio anidro, fornecendo boas conversões para epóxidos com alta seletividade. Mais pesquisa é necessária para esclarecer a natureza dos grupos hidroxilas responsáveis pela atividade catalítica, para produzir materiais que permitem a obtenção de epóxidos com alta seletividade em condições industriais.
\end{abstract}

This account describes our efforts to heterogenize epoxidation catalysts. Anchored and sol-gel entrapped molybdenum were shown to be very selective, but had a strongly reduced activity. On the other hand, molybdenum silicates were very active and stable as long as no diols were present in the reaction mixture. Heterogenized rhenium catalysts were less active but allowed the use of anhydrous hydrogen peroxide as oxidant. However, the high cost and difficult regeneration prevents the industrial use of these catalysts. During these investigations, we found that alumina alone is active in the epoxidation with anhydrous hydrogen peroxide, giving good conversions to epoxides with high selectivity. More research is needed in order to clarify the nature of the hydroxyl groups responsible for its catalytic activity and thus to produce an appropriate material which would allow the obtention of epoxides with high selectivity under industrial conditions.

Keywords: epoxidation, molybdenum, rhenium, alumina, sol-gel process

\section{Introduction}

Epoxides are key raw materials for a wide variety of chemicals such as polyethers, diols and aminoalcohols. ${ }^{1}$ Ethylene oxide, the simplest epoxide, is produced by vapor-phase oxidation of ethylene with air or oxygen over a supported silver catalyst. ${ }^{2}$ However, this method cannot be applied to higher alkenes owing to competing oxidation of allylic $\mathrm{C}-\mathrm{H}$ bonds. Molybdenum catalysts in the homogeneous phase (Arco process) and heterogeneous titanium systems (titanium(IV)/silica, Shell process) are commercially applied to the production of propylene oxide using alkyl hydroperoxides as oxidants. ${ }^{1}$ Recently, the synthesis and application of a titanium-substituted silicalite-1 (TS-1, by Enichem) using aqueous hydrogen peroxide as oxidant has been described. ${ }^{3}$ In spite of the above mentioned catalyzed processes, industry widely uses

*e-mails: rbuffon@iqm.unicamp.br; ulf@iqm.unicamp.br

\# This paper is dedicated to professors Kenneth and Carol Collins peroxo carboxylic acids in stoichiometric amounts for the epoxidation of long chain alkenes, unsaturated esters and acids, terpenes, vegetable oils and polymers. ${ }^{4}$ This method, however, has the disadvantage of forming large amounts of carboxylic acids as by-products. Although the use of homogeneous catalytic systems based on rhenium, manganese and tungsten in combination with hydrogen peroxide has been the subject of intensive research, ${ }^{5-7}$ homogeneous catalysis presents several drawbacks, in particular the recovering of the catalysts at the end of the process, warranting the search for heterogenized epoxidation systems. We wish to present herein an account of our efforts to develop heterogeneous epoxidation catalysts using different approaches for the immobilization of the active species.

\section{Molybdenum Catalysts}

Soluble Mo(VI) compounds are among the most versatile catalysts for the epoxidation of alkenes. ${ }^{8}$ Research aiming 
to the immobilization of this kind of catalyst has focused on the use of organic polymers as supports. Preparation of such polymer-supported catalysts has usually been based on anion exchange, ${ }^{9}$ cation exchange, ${ }^{10,11}$ and chelating ion exchange resins. ${ }^{12-14}$ Among these systems, the one based on polybenzimidazole showed the best performance and stability. ${ }^{15,16}$ The utilization of these systems has been limited by several factors: $i$ ) the lack of stability of the catalyst due to molybdenum leaching; $i i)$ the thermo-oxidative instability of the polymer under reaction conditions; iii) the poor mechanical properties of the organic support. In our laboratories we have tried three other strategies expected to overcome the drawbacks presented by the organic polymers, which are discussed below. In all cases, tert-butyl hydroperoxide (TBHP) was used as the oxidant.

\subsection{Anchoring on functionalized silica}

As a first approach we evaluated the use of organofunctionalized silicas as coordinating agents for molybdenum complexes. Since $\left[\mathrm{Mo}(\mathrm{CO})_{6}\right]$ or $\left[\mathrm{MoO}_{2}(\mathrm{acac})_{2}\right]$ are believed to give the same active species, both precursors were tested. Two kinds of supports were also investigated, bearing one (SiEt1) or two (SiEt2) ethylenediamine groups.

SiEt1 was prepared by the sol-gel method, from tetraethoxysilane and 3-trimethoxysilylpropylenediamine in an acidic medium. Reaction of SiEt1 with glutaraldehyde, followed by reduction, produced SiEt $2 .{ }^{17}$ The supports were allowed to react with a toluene solution of each precursor under reflux. After removal of the solvent and drying under vacuum, the catalysts were analyzed by FT-IR, XPS and Diffuse Reflectance UV-VIS spectroscopies. It turned out that all systems contained mainly Mo(VI) species but in different environments. ${ }^{18}$ All catalysts were tested in the epoxidation of cyclohexene (Table 1) in the presence of a small amount of dichloroethane ([DCE]:[Mo] $=0.04)$. The results showed that $\left[\mathrm{MoO}_{2}(\mathrm{acac})_{2}\right]$ was a better precursor than $\left[\mathrm{Mo}(\mathrm{CO})_{6}\right]$ but that the presence of one or two ethylenediamine groups in the support had no significant effect on the catalytic activity of the resulting systems. In recycling experiments with SiEt1/ $\left[\mathrm{MoO}_{2}(\mathrm{acac})_{2}\right]$ no leaching was observed but the catalytic activity decreased slightly. All reactions were highly selective, the only by-product being chlorocyclohexanol, probably resulting from the reaction between oxidation intermediates and dichloroethane.
Table 1. Summary of the best results obtained with heterogenized molybdenum species

\begin{tabular}{lccr}
\hline Catalyst precursor & $\begin{array}{c}\text { Mo loading } \\
\text { wt. } \%\end{array}$ & $\begin{array}{c}\text { Surface area } \\
\mathrm{m}^{2} \mathrm{~g}^{-1}\end{array}$ & TON \\
\hline SiEt1/[MoO $\left.(\mathrm{acac})_{2}\right]$ & 2.1 & $\sim 30$ & $137^{\mathrm{a}}$ \\
SiEt1/[Mo(CO) $\left.)_{6}\right]$ & 2.4 & $\sim 30$ & $67^{\mathrm{a}}$ \\
SiEt2/[MoO $\left.(\mathrm{acac})_{2}\right]$ & 2.0 & $\sim 30$ & $138^{\mathrm{a}}$ \\
SiEt2/[Mo(CO) $\left.)_{6}\right]$ & 2.4 & $\sim 30$ & $62^{\mathrm{a}}$ \\
SGMo I & 1.5 & 538 & $120^{\mathrm{b}}$ \\
SGMo II & 1.4 & 369 & $50^{\mathrm{b}}$ \\
SGMo III & 3.9 & n.d. & $100^{\mathrm{b}}$ \\
SGMo IV & 0.65 & 262 & $45^{\mathrm{c}}$ \\
SGMo V & 0.50 & 405 & $60^{\mathrm{c}}$ \\
$\left.\left[\mathrm{Mo}_{(\mathrm{OiPr}}\right)_{5}\right]-$ silicate & 0.94 & 368 & $1590^{\mathrm{d}}$ \\
{$\left[\mathrm{MoO}_{2}(\mathrm{acac})_{2}\right]$-silicate } & 1.55 & n.d. & $1123^{\mathrm{e}}$ \\
\hline
\end{tabular}

a Reflux temperature, $4 \mathrm{~h}$, no solvent. [cyclohexene]:[TBHP]:[Mo] $=1150: 192: 1 ;{ }^{\mathrm{b}} 70{ }^{\circ} \mathrm{C}, 4 \mathrm{~h}, 1,2$-dichloroethane (solvent). [cyclohexene]:[TBHP]:[Mo] $=130: 130: 1 ;{ }^{\mathrm{c}} 80{ }^{\circ} \mathrm{C}, 4 \mathrm{~h}$, toluene $($ solvent). [cis-cyclooctene]:[TBHP]:[Mo] $=500: 100: 1 ;{ }^{\mathrm{d}} 60{ }^{\circ} \mathrm{C}, 24 \mathrm{~h}$, no solvent. [cis-cyclooctene]:[TBHP]:[Mo] $=2040: 3060: 1 ;{ }^{\mathrm{e}}$ Not determined.

\subsection{Entrapment via the sol-gel method}

Since the sol-gel methodology has been described as an alternative route to the immobilization of soluble catalysts using either inorganic ${ }^{19}$ or hybrid ${ }^{20}$ matrices, we decided to test this approach to entrap $\left[\mathrm{MoO}_{2}(\mathrm{acac})_{2}\right]$. First, $\left[\mathrm{MoO}_{2}(\mathrm{acac})_{2}\right]$ was entrapped in inorganic matrices prepared by hydrolysis/condensation of tetraethylorthosilicate (TEOS) at different $\mathrm{pH}$ conditions, adapting a procedure described by Blum et al. ${ }^{21}$ Thus, catalysts SGMo I and SGMo III were prepared under $\mathrm{pH}=4$, catalyst SGMo II under $\mathrm{pH}=10$. These conditions clearly affected the properties of the matrix (specific surface area) as well as the catalytic activity (Table 1$){ }^{22}$ The lower activity of catalyst SGMo II could be ascribed to diffusion, expected to be more difficult owing to its smaller surface area and pore volume $\left(0.15 \mathrm{~cm}^{3} \mathrm{~g}^{-1}\right.$, compared with $0.24 \mathrm{~cm}^{3} \mathrm{~g}^{-1}$ for catalyst SGMo I; both systems are microporous). Leaching experiments ${ }^{23}$ carried out with catalyst SGMo I suggested that catalysis was ca. $50 \%$ homogeneous.

In order to avoid leaching, catalyst SGMo IV was prepared using a hydrolysable ligand (N-[3-trimethoxysilyl)propyl]ethylenediamine), with a molar ratio [TEOS]/ [ligand] $=29.3$, to which the molybdenum compound would coordinate. Catalyst SGMo V, a hybrid system, was prepared by the addition of a co-condensation agent $(1,4-$

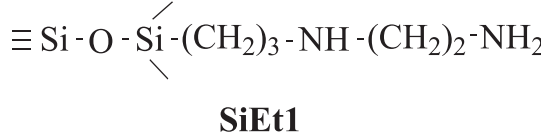

$\equiv \mathrm{Si}-\mathrm{O}-\mathrm{Si}-\left(\mathrm{CH}_{2}\right)_{3}-\mathrm{NH}-\left(\mathrm{CH}_{2}\right)_{2}-\mathrm{NH}-\left(\mathrm{CH}_{2}\right)_{5}-\mathrm{NH}-\left(\mathrm{CH}_{2}\right)_{2}-\mathrm{NH}_{2}$ 
bis(triethoxysilyl)benzene) to the preparation solution ([TEOS $] /[$ co-condensation agent] $=4)$. Although catalyst SGMo IV was characterized by a mesoporous system, it presented the lowest activity among all catalysts prepared by the sol-gel method. When taken all together, these results suggest that the catalytic activity cannot be directly related to the type of the porous system, as diffusion would be easier in a mesoporous matrix. However, at least with catalyst SGMo IV, other factors such as the presence of a chelating ligand and the total surface area must also play a role. Nevertheless, catalysts SGMo IV and SGMo V could be employed in at least four runs without significant changes in activity. ${ }^{22}$

\subsection{Metal-silicates}

Although the preparation of molybdenum-containing silicalite- $1^{24}$ and the Mo-incorporation in the framework of MCM- $41^{25}$ have been reported, the molybdenum incorporation in the sieves was very small and the catalytic properties of those materials were poorly investigated. The sol-gel synthesis of amorphous mesoporous silicates containing titanium, tungsten and molybdenium, which are active in the oxidation of alcohols and in the epoxidation of alkenes with $\mathrm{H}_{2} \mathrm{O}_{2}$, has also been reported. ${ }^{26}$ We synthesized microporous molybdenum-silicates via the sol-gel method, using either $\left[\mathrm{Mo}(\mathrm{OiPr})_{5}\right]$ or $\left[\mathrm{MoO}_{2}(\mathrm{acac})_{2}\right]$ as molybdenum sources, and evaluated their activity and stability. ${ }^{27}$

The metal-silicates were prepared by acid-catalyzed hydrolysis/condensation of tetraethoxysilane (TEOS) in the presence of $\left[\mathrm{Mo}(\mathrm{OiPr})_{5}\right]$ or $\left[\mathrm{MoO}_{2}(\mathrm{acac})_{2}\right]$. The reaction was complete in 4 days. The materials were dried at $65{ }^{\circ} \mathrm{C}$ for $5 \mathrm{~h}$ and then heated at $250^{\circ} \mathrm{C}$ for $5 \mathrm{~h}$. According to UVvis analysis of the material based on $\left[\mathrm{Mo}(\mathrm{OiPr})_{5}\right]$, several Mo species would be present, while FT-IR studies indicated the presence of Mo-O vibrations of tetrahedral molybdate species, suggesting its incorporation in the silicate structure.

Both materials were tested in the epoxidation of ciscyclooctene (Table 1) and turned out to be the most active among all systems studied so far. Leaching experiments performed with the catalyst based on $\left[\mathrm{Mo}(\mathrm{OiPr})_{5}\right]$ (the catalyst was removed by filtration at several stages of the reaction, Figure 1) revealed that catalysis was indeed heterogeneous: as shown in Figure 1, the reaction stopped immediately after removal of the catalyst.

Since the $\left[\mathrm{Mo}(\mathrm{OiPr})_{5}\right]$-based system was the best one, it was also tested in the epoxidation of other alkenes, ${ }^{27}$ which are listed according to their relative catalytic activity (TON and selectivity, respectively, after $8 \mathrm{~h}$ at

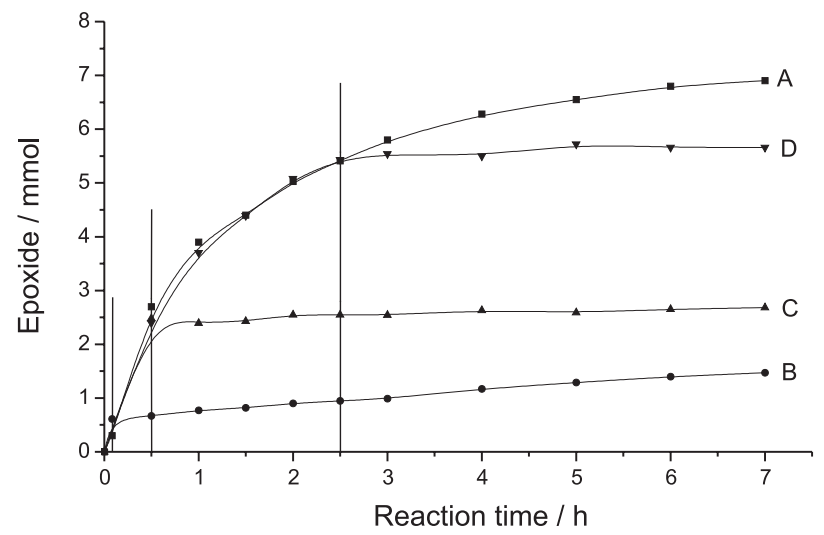

Figure 1. Epoxidation of cyclooctene catalyzed by $\left[\mathrm{Mo}(\mathrm{OiPr})_{5}\right]-$ silicate without (A) and with removal of the catalyst after 5 min (B), $30 \mathrm{~min}(\mathrm{C})$ and $150 \mathrm{~min}(\mathrm{D})$. [cyclooctene]/[TBHP]/[Mo] $=2040 /$ 3060/1. Reaction temperature: $60{ }^{\circ} \mathrm{C}$.

$\left.80{ }^{\circ} \mathrm{C}\right)$ : cyclohexene $(1835 ; 96 \%)>$ cyclooctene $(1794$; $96 \%)>1$-hexene $(1488 ; 92 \%)>$ limonene $(1183 ; 89 \%)>$ 1 -octene $(434 ; 71 \%)>1$-decene $(408 ; 77 \%)>\alpha$-pinene $(265 ; 41 \%)$. These results show that, besides the intrinsic reactivity of the double bond, the alkene size and the accessibility to the active sites of the catalyst are the major limiting factors of this catalyst.

Recycling experiments were carried out with the $\left[\mathrm{Mo}(\mathrm{OiPr})_{5}\right]$-based silicate in the epoxidation of cyclohexene, showing that the activity is almost constant for 5 runs. After the fifth run, a 40\% loss of molybdenum was observed, suggesting the leaching of extra-framework Mo species. However, a total turnover higher than 5000 without considerable decomposition of the catalyst shows that the sol-gel prepared metal-silicates are an interesting option as heterogeneous epoxidation catalysts, warranting an optimization of their preparation conditions.

\section{Rhenium Catalysts}

In spite of the progress achieved in the last decade with the use of rhenium complexes as oxidation catalysts, their heterogenization has received a rather scant interest. Methyltrioxorhenium has been heterogenized in polyvinylpyridines, ${ }^{28,29}$ inorganic oxides, ${ }^{30}$ and anchored on silica tethered with polyethers ${ }^{31}$ or with 2,2'-dipyridylamino groups. ${ }^{32}\left[\mathrm{ReCH}_{3} \mathrm{O}_{3}\right] /$ poly (4-vinylpyridine) could be used in only three runs due the oxidation of the polymer under the reaction conditions. ${ }^{29}$ For the other catalysts, the reported activity was relatively low: turnover numbers vary from 25 to $50 .{ }^{30-32}$ The use of $\left[\mathrm{ReCH}_{3} \mathrm{O}_{3}\right]$ in ionic liquids has also been reported, but its recycling was not mentioned. ${ }^{33}$ We evaluated both the use of $\left[\mathrm{ReCH}_{3} \mathrm{O}_{3}\right]$ and $\left[\mathrm{ReO}_{4}\right]^{-}$as precursors. 


\section{1. $\left[\mathrm{ReCH}_{3} \mathrm{O}_{3}\right]$ immobilized on organic polymers}

Although the heterogenization of $\left[\mathrm{ReCH}_{3} \mathrm{O}_{3}\right]$ in polyvinylpyridines had already been reported, we not only re-investigated this approach but also the possibility of its immobilization in other organic polymers such as nylon 6, nylon 6,6, poly(N-vinylpyrolidone) and poly(4vinylpyridine) cross-linked with 2 or $25 \%$ divinylbenzene. Only the system $\left[\mathrm{ReCH}_{3} \mathrm{O}_{3}\right] /$ poly(4-vinylpyridine)-2\% divinylbenzene led to a significant activity in the epoxidation of soybean oil ([Re]: $\left[\mathrm{H}_{2} \mathrm{O}_{2}\right]$ :[double bonds] = 1:29:25) at $25{ }^{\circ} \mathrm{C}$, using $30 \%$ aqueous $\mathrm{H}_{2} \mathrm{O}_{2}$ as the oxidant: $70 \%$ conversion in 60 min. ${ }^{34}$ Although leaching experiments showed that catalysis was indeed heterogeneous, the catalysts could be used only in 2 runs owing to the oxidative degradation of the polymer, in agreement with literature results. ${ }^{29}$

3.2. $\left[\mathrm{ReCH}_{3} \mathrm{O}_{3}\right]$ entrapped in silica matrices via the solgel method

In this work we heterogenized $\left[\mathrm{ReCH}_{3} \mathrm{O}_{3}\right]$ in hybrid silica matrices via the sol-gel method using 1,4-bis (triethoxysilyl)benzene as a co-condensation agent ("spacer", which would allow for a higher flexibility of the matrix) and 4-(3-triethoxysilylpropylamino)pyridine hydrochloride as a hydrolysable ligand varying their relative proportions (Table 2). The expected anchored rhenium species would be that depicted in the scheme below. ${ }^{35}$

From the data in the table it is clear that the molar ratio $[\mathrm{TEOS}] /\left[\right.$ "spacer"]/[4-pySi(OEt) $\left.{ }_{3}\right]$ strongly affected the surface properties and the catalytic activity of the resulting materials. The absence of the "spacer" as well as its presence in high proportions (catalysts $\operatorname{Re} \mathbf{1}$ and $\operatorname{Re} \mathbf{2}$, respectively) led to similar effects: low surface area, non-porous systems and the highest incorporations of rhenium. All systems were tested in the epoxidation of cis-cyclooctene with hydrogen peroxide in ethyl acetate, leading always to $100 \%$ selectivity for the epoxide. The turnover numbers presented in Table 2 were obtained using a fresh catalyst. The lower values obtained in the first run were due to a rapid decomposition of $\mathrm{H}_{2} \mathrm{O}_{2}$, and not to a deactivation of the catalyst. In most catalytic experiments the molar ratio $\left[\mathrm{H}_{2} \mathrm{O}_{2}\right] /[$ alkene] was 2.3. In all cases $100 \%$ consumption of $\mathrm{H}_{2} \mathrm{O}_{2}$ was observed. This low efficiency with respect to $\mathrm{H}_{2} \mathrm{O}_{2}$, already observed in other $\mathrm{CH}_{3} \mathrm{ReO}_{3}$ heterogenized systems, ${ }^{30}$ accounted for substrate conversions lower than $100 \%$. With systems $\operatorname{Re} 5$ and $\mathbf{R e} \mathbf{6}$, turnover numbers in at least four recycling experiments were almost constant and four times higher
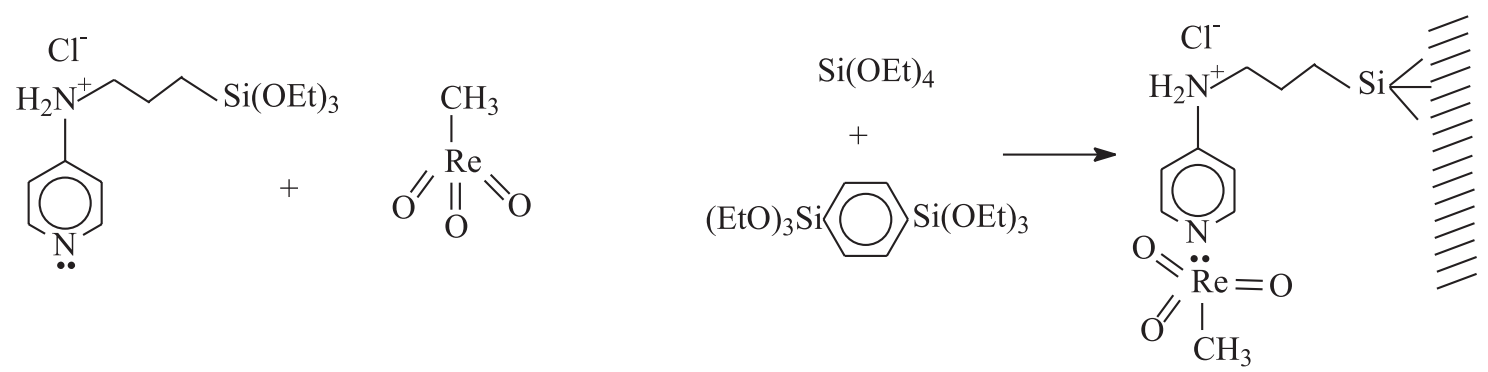

$\operatorname{Re} 2$ - $\operatorname{Re} 6$

Table 2. Summary of relevant data for Re-based catalysts prepared by the sol-gel method.

\begin{tabular}{|c|c|c|c|c|c|c|c|}
\hline Catalyst & $\begin{array}{c}\text { [TEOS]/ } \\
\text { [“spacer”] }\end{array}$ & $\begin{array}{l}\text { [TEOS]/ } \\
\text { [ligand] }\end{array}$ & $\begin{array}{l}\text { [ligand/ } \\
{[\operatorname{Re}]^{\mathrm{a}}}\end{array}$ & $\begin{array}{c}\text { Re loading b } \\
\text { wt. } \%\end{array}$ & $\begin{array}{l}\text { BET } \\
\mathrm{m}^{2} \mathrm{~g}^{-1}\end{array}$ & $\begin{array}{l}\text { Porous volume } \\
\qquad \mathrm{cm}^{3} \mathrm{~g}^{-1}\end{array}$ & $\mathrm{TON}^{\mathrm{d}}$ \\
\hline $\operatorname{Re} 1$ & - & 153 & 0.92 & 0.94 & 95 & n.p. ${ }^{e}$ & 35 \\
\hline $\operatorname{Re} 2$ & $2: 1$ & 105 & 1.05 & 0.54 & 106 & n.p. ${ }^{e}$ & 28 \\
\hline $\operatorname{Re} 3$ & $4: 1$ & 22.5 & 16.3 & 0.18 & 360 & 0.200 & 54 \\
\hline $\operatorname{Re} 4$ & $4: 1$ & 224 & 1.90 & 0.17 & 490 & 0.256 & 120 \\
\hline $\operatorname{Re} 5$ & $5: 1$ & 258 & 1.50 & 0.31 & 360 & 0.184 & $26(140)$ \\
\hline $\operatorname{Re} 6$ & $6: 1$ & 335 & 1.04 & 0.35 & 230 & 0.131 & $41(130)$ \\
\hline
\end{tabular}

${ }^{\mathrm{a}}\left[4-\mathrm{pySi}(\mathrm{OEt})_{3}\right] /[\mathrm{Re}]$ in the preparation solution; ${ }^{\mathrm{b}}$ Determined through ICP-EAS analyses; ${ }^{\mathrm{c}}$ Horvath-Kawazoe method; ${ }^{\mathrm{d}}$ Turnover number $=$ number of moles of cyclooctene converted per mol of rhenium in the first run. Numbers in parentheses are average values obtained in recycling experiments. [Re]:[cis-cyclooctene]: $\left[\mathrm{H}_{2} \mathrm{O}_{2}\right]=1: 140-175: 322-402 ; 6 \mathrm{~h}$; ${ }^{\mathrm{e}}$ non porous. 
than those obtained in the first run (Figure 2). For aged catalysts (stored at room temperature for 5 months), turnover numbers in the first run were lower than those obtained with a fresh sample, but they increased remarkably in the following runs. In the case of catalyst $\operatorname{Re} 4$, reactions with an aged system were quite slow, and a turnover number of 61 was reached only after $10 \mathrm{~h}$ (first run); in the second run, a TON $=158$ was obtained within the same reaction time. When taken all together, these results suggest that some $\mathrm{H}_{2} \mathrm{O}_{2}$ was consumed in reactions with the matrix, maybe increasing the accessibility to the rhenium complex. A higher degree of cross-linking was expected to take place during aging, hampering the access of the substrate to the active site, increasing significantly the reaction time. Leaching experiments proved that catalysis was indeed heterogeneous. ${ }^{23}$ The performance of these systems with other substrates was tested using an aged (and previously used) catalyst 4, keeping an [alkene]/[Re] molar ratio of 175. With styrene, no conversion was observed even after $24 \mathrm{~h}$; in the same reaction time, 1 -octene gave a TON $=28$, and norbornene gave 84 , both with $100 \%$ selectivity. Cyclohexene was also converted to the corresponding epoxide $($ TON = 103). Selectivity, however, was only ca. $76 \%$ since the diol was also formed. The low activity towards styrene and 1-octene may be related to diffusion problems, which seemed to become more important after ageing. The best system, prepared with a [TEOS]:["spacer"]:[4pySi(OEt) ${ }_{3}$ ] molar ratio of 224:56:1 (catalyst $\operatorname{Re} 4$ ), is characterized by high surface area and porous volume, and afforded the highest turnover number in the first run.

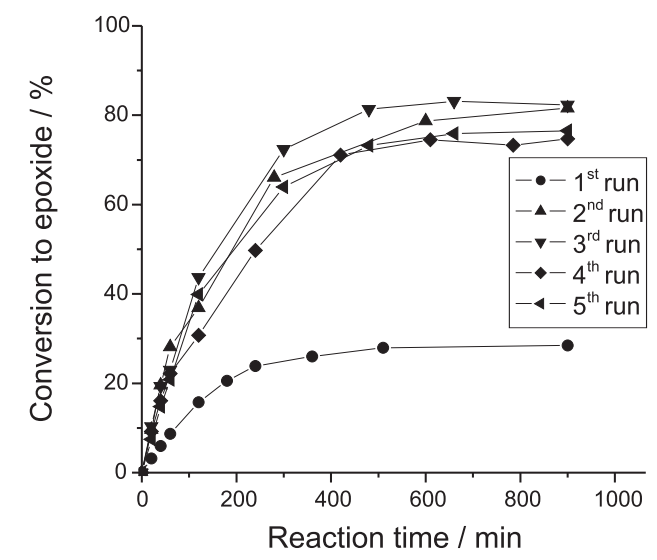

Figure 2. Conversion to epoxide in the epoxidation of ciscyclooctene with system Re 6 in 5 runs. [cis-cyclooctene]/[ $\left.\mathrm{H}_{2} \mathrm{O}_{2}\right] /$ $[\operatorname{Re}]=175 / 402 / 1$. Reaction temperature: $80{ }^{\circ} \mathrm{C}$.

\subsection{Rhenium oxide supported on alumina}

We also evaluated the activity of rhenium oxides supported on zeolite $\mathrm{Y}$, mixed silica-alumina and pure alumina. ${ }^{36}$ These materials were prepared by impregnation of the supports with $\mathrm{Re}_{2} \mathrm{O}_{7}$ or $\left[\mathrm{NH}_{4}\right]\left[\mathrm{ReO}_{4}\right]$ and turned out to be active catalysts in the epoxidation of cyclooctene and cyclohexene using anhydrous $\mathrm{H}_{2} \mathrm{O}_{2}$ in ethyl acetate. Catalyst stability with regard to metal leaching was closely related to the alumina content of the support as almost no rhenium leaching was observed for $\mathrm{ReO}_{4} / \mathrm{Al}_{2} \mathrm{O}_{3}$ up to a 12 wt.\% rhenium loading. At higher rhenium loadings extensive metal leaching was observed, with catalysis taking place in the homogeneous phase. Using a molar ratio $[\mathrm{Re}]:\left[\mathrm{H}_{2} \mathrm{O}_{2}\right]:[$ cyclohexene $]=1: 500: 500$, 12 wt. $\% \mathrm{ReO}_{4} / \mathrm{Al}_{2} \mathrm{O}_{3}$ could be used at least in three consecutive runs without any change in the catalytic activity. In each of the three runs, a $65 \%$ conversion (TON $=325$ ) was reached after $5 \mathrm{~h}$ at $90{ }^{\circ} \mathrm{C}$. The only product, however, was cyclohexanediol. Addition of pyridine to the reaction suspension increased the selectivity to the cyclohexene epoxide from 0 up to $67 \%$, but the activity was highly decreased (TON $=100)$. In the case of cyclooctene, the selectivity to the epoxide was $96 \%$, at a TON of 300.

\section{Alumina Catalysts}

During the research on heterogenized rhenium oxidebased catalysts, we noticed that in some cases the alumina support showed considerable catalytic activity. ${ }^{36}$ Although the epoxidation activity of alumina was already known, ${ }^{37}$ in our experimental conditions (neutral alumina, $24 \mathrm{wt} . \%$ $\mathrm{H}_{2} \mathrm{O}_{2}$ in ethyl acetate, reflux temperature) it was much higher. ${ }^{38}$ Thus, reasonable epoxide yields were obtained for several alkenes ranging from unreactive terminal alkenes (1-octene: $2.6 \mathrm{~g}$ of epoxide per $\mathrm{g}$ of alumina) to the highly reactive terpenes ( $\alpha$-pinene oxide: $3.4 \mathrm{~g}$ of epoxide per $\mathrm{g}$ of alumina).

Since $\alpha$-pinene is a high reactive alkene, forming an epoxide which is very sensitive towards (acid-catalyzed) solvolysis, hydrolysis and rearrangements reactions, it was chosen as a probe to investigate reaction parameters influencing the activity/selectivity of several types of chromatography alumina (weakly acidic, acidic, basic and neutral) ${ }^{39}$ High yields of epoxide were obtained with all tested aluminas. The amount of water, however, had a critical influence on the reaction rate, with almost no activity in the case of $60 \% \mathrm{H}_{2} \mathrm{O}_{2}$. Anhydrous hydrogen peroxide (diluted in acetylacetate) gave a much higher activity. Comparable results were obtained with in situ drying of aqueous hydrogen peroxide by conducting the catalytic experiment under Dean-Stark conditions (49\% conversion/81\% epoxide selectivity against $54 \% / 84 \%$ using anhydrous $\mathrm{H}_{2} \mathrm{O}_{2}$ in ethyl acetate; $10 \mathrm{mmol} \alpha$-pinene, 
$0.50 \mathrm{~g}$ weakly acidic alumina and $20 \mathrm{mmol}_{2} \mathrm{O}_{2}$ for $2 \mathrm{~h}$ under reflux). Under these conditions, a lower average water content can be reached than in the procedure starting with anhydrous hydrogen peroxide. However, in order to use this procedure the volatility of the alkenes must be low enough to prevent evaporation. Table 3 shows some comparative results obtained starting either with anhydrous hydrogen peroxide or with $60 \% \mathrm{H}_{2} \mathrm{O}_{2}$ under Dean Stark conditions.

Table 3. Alumina catalyzed epoxidation of alkenes using aqueous and anhydrous $\mathrm{H}_{2} \mathrm{O}_{2}{ }^{\mathrm{a}}$

\begin{tabular}{|c|c|c|c|c|}
\hline Alkene & \multicolumn{2}{|c|}{$\begin{array}{l}60 \% \mathrm{H}_{2} \mathrm{O}_{2} / \\
\text { Dean Stark }\end{array}$} & \multicolumn{2}{|c|}{$\begin{array}{c}\text { anhydrous } \\
\mathrm{H}_{2} \mathrm{O}_{2} / \text { EtOAc }\end{array}$} \\
\hline Cyclohexene & & & 6 & 76 \\
\hline Cycloheptene & & & 24 & 77 \\
\hline Cyclooctene & 8 & 90 & 24 & 92 \\
\hline 1-methylcyclohexene & 4 & 42 & 4 & 88 \\
\hline Limonene & 4 & $83^{\mathrm{b}}$ & 4 & 77 \\
\hline$\alpha$-pinene & 4 & 69 & 4 & 65 \\
\hline \multirow[t]{2}{*}{$\gamma$-terpinene } & 4 & $41^{\mathrm{c}}$ & & \\
\hline & 22 & $40^{\mathrm{d}}$ & & \\
\hline 3-carene & 3 & 87 & & \\
\hline
\end{tabular}

a $10 \mathrm{mmol}$ alkene, $1 \mathrm{mmol}$ dibutyl ether, $0.50 \mathrm{~g}$ alumina (Aldrich, weakly acidic), $10 \mathrm{ml}$ ethyl acetate, $20 \mathrm{mmol} \mathrm{H}_{2} \mathrm{O}_{2}$, reflux under nitrogen; ${ }^{\mathrm{b}}$ sum of mono- and di-epoxides; ${ }^{\mathrm{c}}$ monoepoxides plus $31 \%$ cymene; ${ }^{\mathrm{d}}$ diepoxide plus $36 \%$ cymene.

Further experiments concerning the stability of the formed epoxide under the reaction conditions revealed that a very small amount of water was necessary in the reaction medium to prevent decomposition of both the epoxide and the hydrogen peroxide.

To confirm that the catalysis is truly heterogeneous, epoxidation of limonene was stopped after $1 \mathrm{~h}(45 \%$ conversion) by hot filtration of the catalyst. Submission of the filtrate to reaction conditions gave no significant increase in conversion, ${ }^{38}$ showing that no active compounds had leached. In a recycling experiment using 2-methylocta-2,7-diene, two consecutive runs gave the same yield and selectivity. ${ }^{39}$ More detailed studies using limonene showed a great decrease in the conversion by the fifth run (ca. 50\%), which remained constant for at least more 3 runs..$^{40}$

Aluminas obtained by sol-gel methods are normally less active than the commercial alumina. However, the use of monomeric alumina sec-butoxide and of oxalic acid to form stable alumina mesophases allows a very active alumina to be obtained, which catalyses the epoxidation of the less reactive cyclohexene with hydrogen peroxide in $98 \%$ yield. ${ }^{41}$

\section{Conclusions and Perspectives}

Anchoring or entrapping molybdenum catalysts on silica matrices strongly reduced their epoxidation activity, thus turning them inappropriate for larger scale application. On the other hand, the molybdenum silicate, prepared from $\left[\mathrm{Mo}(\mathrm{OiPr})_{5}\right]$ and tetraethoxysilane, showed to be stable and very active, allowing turnover numbers higher than 5000 before leaching of molybdenum started. This leaching was probably caused by $\alpha$-dihydroxy species formed in the ring opening of the epoxide. Further research is needed to avoid this reaction and make the catalyst sufficiently stable for industrial use.

Rhenium catalysts are interesting because hydrogen peroxide can be used as oxidant. $\left[\mathrm{ReCH}_{3} \mathrm{O}_{3}\right]$ entrapped on hybrid silica matrices formed a stable catalytic system; however, turnover numbers were relatively small. Rhenium oxide supported on alumina was stable under catalytic conditions, allowing a turnover number of approximately 1000 in three consecutive runs. However, ring opening was observed for some of the epoxides.

In our opinion, simple aluminas are the most interesting heterogeneous epoxidation catalysts as they are cheap, environmental friendly and showed no leaching. We were able to obtain up to $50 \mathrm{~g}$ of epoxides per $\mathrm{g}$ of alumina, and the alumina could be used in at least 8 runs with a $50 \%$ loss of activity. However, the nature of the hydroxyl groups responsible for the catalytic activity is not yet understood, warranting further investigations with the aim of preparing tailor-made catalysts.

\section{Acknowledgements}

Financial support from FAPESP and CNPq is gratefully acknowledged. We also would like to thank all our coworkers whose names appear in the references.

\section{References}

1. Sheldon, R. A. In Applied Homogeneous Catalysis with Organometallic Compounds; Cornils, B.; Herrmann, W. A., eds; VCH: Weinheim, 1996, vol. 1, p. 411.

2. Kilty, P. A.; Sachtler, W. M. H.; Catal. Rev. 1974, 10, 1.

3. Clerici, M.; Ingallina, P.; J. Catal. 1993, 140, 71.

4. Sienel, G.; Rieth, R.; Rowbottom, K.; In Ullmann's Encyclopedia of Industrial Chemistry; Gerhartz, W.; Yamamoto, Y. S.; Kaudy, L.; Rounsaville, J. F.; Schulz, G. eds.; $5^{\text {th }}$ ed., VCH: Weinheim, 1987, vol. A9, p. 531.

5. Gansäuer, A.; Angew. Chem., Int. Ed. Engl. 1997, 36, 2591.

6. de Vos, D. E.; Sels, B. F.; Reynaers, M.; Subba Rao, Y. V.; Jacobs, P. A.; Tetrahedron Lett. 1998, 39, 32321. 
7. Sato, K.; Aoki, M.; Ogawa, M.; Hashimoto, T.; Noyori, R.; J. Org. Chem. 1996, 61, 8310.

8. Parshall, G. W.; Ittel, S. D.; Homogeneous Catalysis: The Applications and Chemistry of Catalysis by Soluble Transition Metal Complexes, Wiley: New York, 1992.

9. Sobczak, J.; Ziólkowski, J.; J. Mol. Catal. 1978, 3, 165.

10. Ivanov, S.; Boeva, R.; Tanielyau, S.; J. Catal. 1979, 56, 150.

11. Boeva, R.; Kotov, S.; Jordanov, N. I.; React. Kinet. Catal. Lett. 1984, 24, 239.

12. Bhaduri, S.; Khwaja, H.; J. Chem. Soc., Dalton Trans. 1983, 415.

13. Yokoyama , T.; Nishizawa, M.; Kimura, T.; Suzuki, T. M.; Bull. Chem. Soc. Jpn. 1985, 58, 3271.

14. Sherrington, D. C.; Simpson, S.; J. Catal. 1991, 131, 115.

15. Miller, M. M.; Sherrington, D. C.; J. Catal. 1995, 152, 368.

16. Miller, M. M.; Sherrington, D. C.; J. Catal. 1995, 152, 377.

17. Cestari, A. R.; Bruns, R. E.; Airoldi, C.; Colloids Surf. A 1996, 117, 7.

18. Barradas, E. F. M.; Cestari, A. R.; Airoldi, C.; Buffon, R.; Braz. J. Chem. Eng. 1998, 15, 146.

19. Blum, J.; Avnir, D.; Schumann, H.; Chemtech 1999, 29, 32.

20. Lindner, E.; Schneller, T.; Auer, F.; Mayer, H. A.; Angew. Chem., Int. Ed. Engl. 1999, 38, 2155.

21. Blum, J.; Rosenfeld, A.; Polak, N.; Israelson, O.; Schumann, H.; Avnir, D.; J. Mol. Catal. A: Chem.. 1996, 107, 217.

22. Teixeira, S.; Dallmann, K.; Schuchardt, U.; Buffon, R.; J. Mol. Catal. A: Chem. 2002, 182-183, 167.

23. Sheldon, R. A.; Wallau, M.; Arends, I. W. E. C.; Schuchardt, U.; Acc. Chem. Res. 1998, 31, 485.

24. Raghavan, P. S.; Ramaswamy, V.; Upadhya, T. T.; Sudalai, A.; Ramaswamy, A. V.; Sivasanker, S.; J. Mol. Catal. A 1997, 122, 75.

25. Rana, R. K.; Viswanathan, B.; Catal. Lett. 1998, 52, 25.

26. Neumann, R.; Levin-Elad, M.; J. Catal. 1997, 166, 206.
27. Arnold, U.; da Cruz, R. S.; Mandelli, D.; Schuchardt, U.; J. Mol. Catal. A: Chem. 2001, 165, 149.

28. Herrmann, W. A.; Fischer, R. W.; Marz, D. W.; Angew. Chem., Int. Ed. Engl. 1991, 30, 1638.

29. Herrmann, W. A.; Wagner, W.; Kuchler, J. G.; Weichselbaumer, G.; Fischer, R. W.; US Pat. 5, 155,247 1992 (CA: 114: 143714u)

30. Zhu, Z.; Espenson, J. H.; J. Mol. Catal. A: Chem. 1997, 121, 139.

31. Neumann, R.; Wang, T.-J.; Chem. Commun. 1997, 1915.

32. Wang, T.-J.; Li, D.-C.; Bai, J.-H.; Huang, M.-Y.; Jiang, Y.-Y.; J. M. S. - Pure Appl. Chem. A 1998, 35, 531.

33. Owens, G. S.; Abu-Omar, M. M.; Chem. Commun. 2000, 1165.

34. Sales, H.; Mandelli, D.; Cesquini, R.; Sato, S.; Schuchardt, U.; In Atas do XVII Simpósio Íbero-Americano de Catálise, Porto, 2000, C247.

35. Dallmann, K.; Buffon, R.; Catal. Commun. 2000, 1, 9.

36. Mandelli, D.; van Vliet, M. C. A.; Arnold, U.; Sheldon, R. A.; Schuchardt, U.; J. Mol. Catal. A: Chem. 2001, 168, 165.

37. Rebek, J.; McCready, R.; Tetrahedron Lett. 1979, 4337.

38. Mandelli, D.; van Vliet, M. C. A.; Sheldon, R. A.; Schuchardt, U.; Appl. Catal. A: Gen. 2001, 219, 209.

39. van Vliet, M. C. A.; Mandelli, D.; Arends, I. W. C. E.; Schuchardt, U.; Sheldon, R. A.; Green Chemistry 2001, 3, 243.

40. Woitiski, C. B.; Ambiel, G.; Schuchardt, U.; Carvalho, W. A.; Mandelli, D.; Atas do XVIII Simpósio Iberoamericano de Catálise, Margarit Island, 2002, QF-E-2.

41. Cesquini, R.G.; Silva, J.M.S.; Woitiski, C.B.; Mandelli, D.; Rinaldi, R.; Schuchardt U.; Adv. Synth. Catal. 2002, 344, 911.

Received: March 25, 2002

Published on the web: March 24, 2003

FAPESP helped in meeting the publication costs of this article. 